\title{
The Elastin Receptor Complex: A Unique Matricellular Receptor with High Anti-tumoral Potential
}

\begin{abstract}
Amandine Scandolera', Ludivine Odoul, Stéphanie Salesse, Alexandre Guillot, Sébastien Blaise, Charlotte Kawecki, Pascal Maurice, Hassan El Btaouri, Béatrice Romier-Crouzet, Laurent Martiny, Laurent Debelle and Laurent Duca*
\end{abstract}

UMR CNRS/URCA 7369, SFR CAP Santé, Université de Reims Champagne Ardenne, Faculté des Sciences, Reims, France

Elastin, one of the longest-lived proteins, confers elasticity to tissues with high mechanical constraints. During aging or pathophysiological conditions such as cancer progression, this insoluble polymer of tropoelastin undergoes an important degradation leading to the release of bioactive elastin-derived peptides (EDPs), named elastokines. EDP exhibit several biological functions able to drive tumor development by regulating cell proliferation, invasion, survival, angiogenesis, and matrix metalloproteinase expression in various tumor and stromal cells. Although, several receptors have been suggested to bind elastokines $\alpha_{v} \beta_{3}$ and $\alpha_{v} \beta_{5}$ integrins, galectin$3)$, their main receptor remains the elastin receptor complex (ERC). This heterotrimer comprises a peripheral subunit, named elastin binding protein (EBP), associated to the protective protein/cathepsin A (PPCA). The latter is bound to a membrane-associated protein called Neuraminidase-1 (Neu-1). The pro-tumoral effects of elastokines have been linked to their binding onto EBP. Additionally, Neu-1 sialidase activity is essential for their signal transduction. Consistently, EDP-EBP interaction and Neu-1 activity emerge as original anti-tumoral targets. Interestingly, besides its direct involvement in cancer progression, the ERC also regulates diabetes outcome and thrombosis, an important risk factor for cancer development and a vascular process highly increased in patients suffering from cancer. In this review, we will describe ERC and elastokines involvement in cancer development suggesting that this unique receptor would be a promising therapeutic target. We will also discuss the pharmacological concepts aiming at blocking its pro-tumoral activities. Finally, its emerging role in cancer-associated complications and pathologies such as diabetes and thrombotic events will be also considered.

Keywords: extracellular matrix, elastokines, ERC, neuraminidase-1, therapeutic targets

\section{CANCER DEVELOPMENT AND EXTRACELLULAR MATRIX}

Despite a great progress concerning predictive biomarkers, diagnostic and prognostic strategies, cancer remains the second leading cause of death worldwide after cardiovascular diseases. In 2012, approximately 14 million of new cases and 8.2 million of cancer related deaths have been reported, according to the World Health Organization.

Although, the development of cancer was initially thought to be initiated when a single mutated cell begins to proliferate abnormally leading to the formation of primary tumor (in situ), the 
polyclonal origin of tumors has now been proposed (Parsons, 2008). Malignant cells then cross the tissue, possibly the basement membrane, and invade the extracellular matrix (ECM). From there, invasive tumor cells can spread throughout the body via the lymphatic or circulatory systems creating metastatic tumors.

Extracellular matrix remodeling is crucial for regulating tissue homeostasis but also contributes to disease when it is dysregulated. It is composed of macromolecules such as collagens, elastin, laminins, fibronectin, and proteoglycans. Those components interact with cell receptors, transmitting signals that orientate cell adhesion, migration, proliferation, apoptosis, survival, or differentiation. ECM does not only behave as a simple physical support for tissue integrity and plasticity. It is also a reservoir of growth factors, proteases, and other signaling molecules (Hynes, 2009).

During tumor progression, ECM is modified by proteases secreted by both normal and tumor cells. This degradation generates bioactive fragments called matrikines or matricryptines (Davis et al., 2000; Maquart et al., 2004). Matrikines can modulate cell proliferation, migration, invasion, apoptosis, angiogenesis as well as the production and activation of matrix metalloproteinases (MMPs) and the plasminogen system (Bellon et al., 2004; Maquart et al., 2005). In this review, we will focus on elastin, and especially on pro-tumoral activities of elastin-derived peptide (EDP) through their unique receptor, the elastin receptor complex (ERC).

\section{ELASTIN}

\section{Elastic Fibers Components}

The elastin synthesis, begins during the fetal period (Uitto et al., 1991) and peaks just before birth. Elastogenesis then decreases rapidly to disappear at puberty (Swee et al., 1995). The half-life of elastin is about 70 years (Petersen et al., 2002) and neo-synthesis is low or inexistent. In addition, the ability to form functional elastic fibers is lost. Elastic fibers are essential components of the ECM and are responsible for elasticity of vertebrate tissues. They are found in abundance in tissues subjected to high mechanical stresses requiring repeated cycles of expansion and back to their original state such as the skin, lungs, tendons, or arteries.

Elastic fibers are complex macromolecular assemblies consisting of a coat of fibrillin-rich microfibrils surrounding a heart of elastin (Kielty et al., 2002). The architecture of mature elastic fibers is extremely complex and tissue-specific, reflecting the particular functions they have in tissues. Elastin is a highly hydrophobic polymer of crosslinked-tropoelastin monomers. Microfibrils are made by glycoproteins such as fibrillin-1, fibrillin-2, microfibril-associated glycoprotein-1 (MAGP-1), emilins, latent transforming growth factor $\beta$-binding proteins (LTBPs), microfibrillar-associated proteins (MFAPs), and Fibulins (Mithieux and Weiss, 1995). The tropoelastin sequence is composed of alternating domains of very hydrophobic repeating units (which ensure elasticity) and lysine-rich domains. These lysine residues are essential, since the oxidative deamination of their side chains allows the formation of mature elastin covalent crosslinks, i.e., desmosine and isodesmosine, that confer a great mechanical resistance to the elastomer.

\section{Biosynthesis}

Elastin is synthesized and secreted from various cell types such as endothelial cells and fibroblasts (Rodgers and Weiss, 2005).

After a major splicing, mature tropoelastin mRNA is exported out of the nucleus and its translation occurs on the surface of the rough endoplasmic reticulum (RER) forming a polypeptide of about $70 \mathrm{kDa}$ with a $\mathrm{N}$-terminal signal sequence of 26 amino acids which is cleaved when the protein reached the RER lumen (Grosso and Mecham, 1988). After release of the signal peptide, the protein is associated with elastin-binding protein (EBP) to prevent its aggregation and premature degradation (Hinek et al., 1995). The EBP-tropoelastin assembly is then directed to the plasma membrane. EBP is secreted and binding of galactose sugars on its galactolectin site causes the release of tropoelastin, which is then aligned and properly incorporated into the growing elastic fiber (Privitera et al., 1998). After tropoelastin release, EBP is recycled and can accompany another tropoelastin molecule.

\section{ELASTIN DEGRADATION AND ELASTIN PEPTIDES}

Elastases cleave insoluble and soluble elastin and include serine-, cysteine-, and metallo-proteinases. The serine proteinases neutrophil elastase (Ela-2), cathepsin G, and proteinase-3 and four members of the cysteine cathepsin family (L, S, K, and V) display elastinolytic activity. Moreover, four MMP are elastases (MMP-2, MMP-7, MMP-9, MMP-12). Some generated EDP harbor a GxxPG consensus motif (where $x$ represents any amino acid) adopting a type VIII $\beta$-turn, essential for their bioactivity (Brassart et al., 2001). These bioactive EDP are referred as elastokines and the typical elastokine is the VGVAPG peptide, found in the domain encoded by exon 24 of human tropoelastin. Other bioactive GxxPG motifs, GVYPG, GFGPG and GVLPG, and longer elastokines have been reported (Heinz et al., 2012). For instance, MMP-7, -9, and -12 have been shown to generate the bioactive peptides YTTGKLPYGYGPGG, YGARPGVGVGGIP, and PGFGAVPGA (Heinz et al., 2010).

Elastokines contribute to cancer progression by stimulating several capacities of tumor cells such as an elevated expression and secretion of proteases, strongly potentiating their migration and matrix invasion properties (Brassart et al., 1998; Ntayi et al., 2004; Coquerel et al., 2009; Toupance et al., 2012; Donet et al., 2014; Table 1). Interestingly, elastokines present potent chemotactic activity on melanoma cells and their presence at a distant organ might contribute to metastasis (Pocza et al., 2008). EDP have also been reported to induce in vitro proliferation of glioblastoma (Hinek et al., 1999), and astrocytoma human cell lines (Jung et al., 1998) as well as murine melanoma cell line (Devy et al., 2010). Our laboratory was the first to demonstrate in vivo that EDP enhanced murine melanoma cells growth and invasion (Devy et al., 2010). 
Elastokines have also biological effects on normal cells. They stimulate migration and proliferation of monocytes and skin fibroblasts (Senior et al., 1984; Shiratsuchi et al., 2010). They upregulate MMP expression by fibroblasts inducing a remodeling program in favor of melanoma cell invasion. Elastokines exhibit pro-angiogenic activity through MT1-MMP and NO-mediated increase of endothelial cell migration and tubulogenesis (Robinet et al., 2005; Fahem et al., 2008; Gunda et al., 2013). A wide range of biological effects on immune cells was reported in response to EDP stimulation (Antonicelli et al., 2007). Among them, the chemotactic activity (Nowak et al., 1989; Hance et al., 2002; Houghton et al., 2006; Guo et al., 2011) and elastases production (Hauck et al., 1995; Péterszegi et al., 1997; Varga et al., 1997) amplify elastolysis and increase inflammatory cells recruitment at the tumor site.

\section{RECEPTORS AND SIGNALING}

The biological effects of EDP are mediated by their binding to their cell surface receptors. Among them, the ERC is the most prominent but others potential receptors have also been reported, namely galectin-3 (Pocza et al., 2008) and integrins $\alpha_{v} \beta_{3}$ and $\alpha_{v} \beta_{5}$ (Rodgers and Weiss, 2004; Lee et al., 2014b).

Galectin-3 is expressed in normal and tumor cells and possesses diverse biological functions associated with inflammatory response such as adhesion, cell differentiation, cell migration, and cytokine production. It also modulates others biological functions linked to tumor development like angiogenesis, tumor progression, proliferation, chemotactic, and cell-matrix interactions (Fortuna-Costa et al., 2014). It was moreover reported that galectin-3 is able to interact with both

TABLE 1 | Cancer-associated biological effects of EDP.

\begin{tabular}{|c|c|c|}
\hline Biological effects & Cell types & EDPs cancer-associated biological effects \\
\hline Angiogenesis & Endothelial cells & $\begin{array}{l}\text { Nackman et al., 1997; Robinet et al., 2005; Daamen et al., 2008; Fahem et al., 2008; Gunda et al., } \\
2013\end{array}$ \\
\hline \multirow[t]{2}{*}{ Apoptosis and cell survival } & Fibroblasts & Cantarelli et al., 2009 \\
\hline & Lymphocytes & Péterszegi and Robert, 1998; Péterszegi et al., 1999 \\
\hline \multirow[t]{4}{*}{ Adhesion } & Fibroblasts & $\begin{array}{l}\text { Hornebeck et al., 1986; Groult et al., 1991; Yamamoto et al., 2002; Rodgers and Weiss, 2004; Bax } \\
\text { et al., 2009; Akhtar et al., } 2011\end{array}$ \\
\hline & Astrocytoma & Jung et al., 1999 \\
\hline & Carcinoma & Timar et al., 1991; Svitkina and Parsons, 1993 \\
\hline & Melanoma & Timar et al., 1991; Svitkina and Parsons, 1993 \\
\hline \multirow[t]{6}{*}{ Proliferation } & Fibroblasts & $\begin{array}{l}\text { Ghuysen-Itard et al., 1992; Kamoun et al., 1995; Tyagi et al., 1996; Tajima et al., 1997; Duca et al., } \\
\text { 2005; Shiratsuchi et al., } 2010\end{array}$ \\
\hline & Lymphocytes & Poggi and Mingari, 1995; Péterszegi et al., 1996 \\
\hline & Melanoma & Devy et al., 2010 \\
\hline & Astrocytoma & Jung et al., 1998 \\
\hline & Glioma & Hinek et al., 1999 \\
\hline & Endothelial cells & Ito et al., 1998; Dutoya et al., 2000 \\
\hline \multirow[t]{9}{*}{ Tumor invasion and proteases release } & Fibroblasts & $\begin{array}{l}\text { Gminski et al., 1991a,b; Archilla-Marcos and Robert, 1993; Landeau et al., 1994; Brassart et al., } \\
\text { 2001; Huet et al., } 2001\end{array}$ \\
\hline & Endothelial cells & Robinet et al., 2005; Fahem et al., 2008; Siemianowicz et al., 2010, 2015 \\
\hline & Monocytes & Fülöp et al., 1986; Varga et al., 1997 \\
\hline & Lymphocytes & Péterszegi et al., 1996, 1999 \\
\hline & Melanoma & Ntayi et al., 2004; Pocza et al., 2008; Devy et al., 2010 \\
\hline & Glioma & Coquerel et al., 2009 \\
\hline & 3LL-HM carcinoma & Timar et al., 1991 \\
\hline & Lung cancer & Toupance et al., 2012 \\
\hline & HT1080 fibrosarcoma & Brassart et al., 1998; Huet et al., 2002;Donet et al., 2014 \\
\hline \multirow[t]{9}{*}{ Chomotaxis and migration } & Keratinocytes & Fujimoto et al., 2000 \\
\hline & Fibroblasts & $\begin{array}{l}\text { Senior et al., 1982, 1984; Mecham et al., 1989; Grosso and Scott, 1993b; Duca et al., 2005; } \\
\text { Shiratsuchi et al., } 2010\end{array}$ \\
\hline & Eodothelial cells & Long et al., 1989; Skeie and Mullins, 2008; Skeie et al., 2012 \\
\hline & Monocytes & $\begin{array}{l}\text { Senior et al., 1980, 1984; Bisaccia et al., 1994; Castiglione Morelli et al., 1997; Uemura and } \\
\text { Okamoto, 1997; Hance et al., 2002; Houghton et al., } 2006\end{array}$ \\
\hline & Macrophages & Kamisato et al., 1997; Guo et al., 2006, 2011 \\
\hline & 3LL-HM carcinoma & Timar et al., 1991 \\
\hline & M27 lung cancer & Blood et al., 1988; Blood and Zetter, 1989, 1993; Yusa et al., 1989; Grosso and Scott, 1993a \\
\hline & Melanoma & Mecham et al., 1989; Pocza et al., 2008 \\
\hline & HT1080 fibrosarcoma & Donet et al., 2014 \\
\hline
\end{tabular}




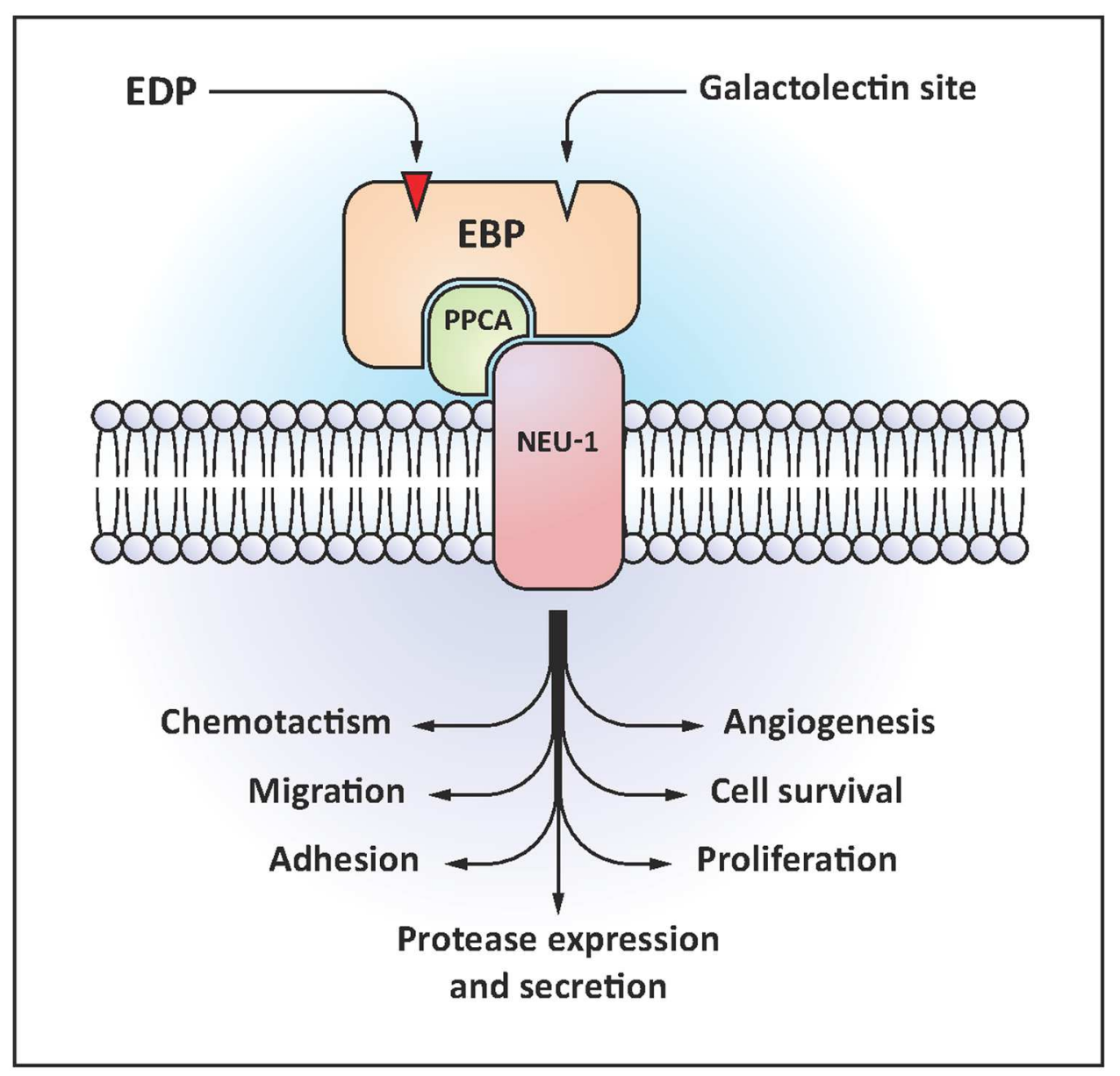

FIGURE 1 | Elastin receptor complex (ERC) structural organization and EDP-induced biological effects.

soluble and insoluble elastin in a lactose-dependent manner (Ochieng et al., 2004). This interaction can modulate tumor development as observed by the ability of some specific EDP, such as VGVAPG and VAPG, to amplify melanoma invasion (Pocza et al., 2008).

Integrin $\alpha_{\mathrm{v}} \beta_{3}$ regulates diverse biological functions such as cell adhesion, proliferation and migration (Byzova et al., 1998). $\alpha_{\mathrm{v}} \beta_{3}$ mainly binds ligands through RGD sequence recognition but it can also recognize others ligands that do not harbor this motif. Indeed, integrin $\alpha_{v} \beta_{3}$ recognizes with high affinity the RKRK sequence present in the C-terminal domain of tropoelastin (Bax et al., 2009). Moreover, a recent study has shown the ability for $\alpha_{\nu} \beta_{5}$ to bind tropelastin involving the central region of the protein (Lee et al., 2014b).

The ERC is a heterotrimeric receptor binding elastokines presenting the GxxPG consensus sequence (Figure 1). This receptor contains a peripheral $67-\mathrm{kDa}$ protein named EBP (accession number P16278-2), and two membrane-associated proteins, the protective protein/cathepsin A (PPCA, $55-\mathrm{kDa}$, accession number P10619) and neuraminidase-1 (Neu-1, 61$\mathrm{kDa}$, accession number Q99519; Duca et al., 2007). EBP is an enzymatically inactive spliced variant of lysosomal $\beta$-galactosidase (Privitera et al., 1998). EBP possesses two functional binding sites: the elastin site on which EDP binding triggers signaling pathways, and the galactolectin site whom occupancy by galactosugars induces EDP release and dissociation of the complex (Mecham et al., 1991). When EDP bind to EBP, neuraminidase- 1 is activated and catalyzes the desialylation of adjacent gangliosides such as $\mathrm{GM}_{3}$ [ $N$-acetylneuraminic$\alpha$-(2-3)-galactosyl- $\beta$-(1-4)-glucosyl-(1-1')-ceramide] generating lactosylceramide (LacCer) production (Rusciani et al., 2010; Scandolera et al., 2015). LacCer is a second messenger able to activate intracellular signals. Intracellular signaling pathways modulated by EDP depend on the cell type. Duca et al. (2002) showed that pro-MMP-1 induction mediated by EDP in human dermal fibroblasts involves the activation of MEK1/2/ERK1/2 pathway through a signal dependent on PKA and PI3K. Moreover, complementary works demonstrated that EDP are able to modulate signaling pathways involving modules such as Ras-Raf-1-MEK1/2-ERK1/2, Gi-p110 $\gamma$-Raf-1-MEK1/2ERK1/2, cAMP-PKA-B-Raf-MEK1/2-ERK1/2, NO-cGMP-PKGRaf-1-MEK1/2-ERK1/2 or Gi-p110 $\gamma$-Akt-caspase9-Bad-Foxo3A. They also induce $\mathrm{Ca}^{2+}$ mobilization (Jacob et al., 1987; Faury et al., 1998; Duca et al., 2005; Fahem et al., 2008). 
Although EDP are the main ligands of ERC, bioactive $\mathrm{xGxxPG}$ motifs are found in numerous matrix protein sequences. For instance, laminin B1 chain harbors a LGTIPG sequence that triggers elastin-like signaling, inducing pro-tumoral activities, and was identified as a ligand of this receptor in melanoma cells. That is why EBP was first called the $67-\mathrm{kD}$ elastin/laminin binding protein (Mecham et al., 1989; Hinek, 1994).

\section{ANTI-ERC THERAPEUTIC STRATEGIES}

Limiting or blocking the deleterious effects of EDP/ERC interaction can be achieved either by limiting EDP generation or by acting directly on the ERC and its signaling pathways. As this review is focused on ERC, we will not detail here elastases inhibition strategies.

\section{Targeting EBP}

Blocking the binding of EDP on EBP can be achieved either by using the V14 peptide or a galactoside. The V14 peptide (VVGSPSAQDEASPL) is derived from EBP sequence and can bind EDP. As a consequence, excess V14 can trap circulating EDP thereby blocking their effects (Robinet et al., 2007). Alternatively, the use of galactosugars (mostly lactose or chondroitin sulfate) leads to the shedding of EBP from the complex and blocks the corresponding signaling (Blaise et al., 2013). Although V14 and galactosugars helped to better understand EDP biology, their selective delivery at the site of vascular injury is still an issue.

\section{Targeting Neu-1}

The catalytic activity of Neu-1 is required for proper EDP signaling. As a consequence, its inhibition blocks EDPdriven signals. The 2-deoxy-2,3-dehydro- $N$-acetylneuraminic acid (ddNeu5Ac) inhibitor is currently used as a sialidase inhibitor to block EDP effects (Duca et al., 2007). However, this compound also inhibits other sialidases precluding its therapeutic use.

An attempt was made to design and synthesize inhibitors for human neuraminidases (Magesh et al., 2009) but the results were not satisfactory. Indeed, selectivity was not achieved, probably because the structures of human sialidases are not fully described.

Recently, O'Shea et al. (2014) used oseltamivir phosphate to target Neu-1 and disable cancer cell survival in human pancreatic cancer with acquired chemoresistance. This study suggests that Tamiflu could be possibly used to selectively block Neu-1.

\section{Blocking EDP-Mediated Signaling Pathways}

In human skin fibroblasts, Neu-1 promotes the local conversion of the $\mathrm{GM}_{3}$ ganglioside into LacCer following EDP treatment. LacCer can therefore be regarded as the second messenger of the complex (Rusciani et al., 2010). Thus, blocking the signaling pathways triggered by LacCer will suppress EDP effects. In this context, PI3Kg is a promising target as this kinase is central to EDP-related signaling (Duca et al., 2005).

Besides this direct signaling, Neu-1 is also known for its ability to desialylate other membrane residing glycoconjugates, notably receptors. During the last decade, Neu-1 has been shown to modulate insulin receptor signaling (Blaise et al., 2013) and to regulate TLR4 (Amith et al., 2010), Trk A (Jayanth et al., 2010), PDGF-BB and IGF receptors (Hinek et al., 2008), EGF and MUC1 receptors (Lillehoj et al., 2012), and CD31 (Lee et al., 2014a). Consequently, this ERC subunit now emerges not only as a catabolic enzyme but also as a regulator of signaling platforms (Pshezhetsky and Hinek, 2011).

Efforts are now made to understand the intricate network of Neu-1 partners and how they interact each other in order to devise new strategies aiming at selectively impeding these interactions.

\section{ERC INVOLVEMENT IN CANCER-ASSOCIATED PROCESSES}

\section{Diabetes}

Type 2 diabetes leads to many micro- and macrovascular complications implicating several molecular factors and with significant impact in terms of morbidity and mortality. For example, type 2 diabetes mellitus is associated with an increase in the expression of MMPs, especially MMP-2 and 9, and an increase in the degradation of elastin and, thus, the generation of EDP (Hopps and Caimi, 2012). EDP immunogenic properties favor the formation of anti-elastin antibodies, which concentrations are greatly increased in diabetic patients as compared to non-diabetic subjects (Fulop et al., 1990).

Cancer is a well-known complication of diabetes. Indeed, cancer development is more frequent in diabetic people than in the general population. According to recent studies and metaanalyzes, cancers involving the pancreas (Morrison, 2012), liver (Giovannucci et al., 2010), colon (Larsson et al., 2005), breast (Larsson et al., 2007), urinary tract (Larsson et al., 2006), and the endometrium (Friberg et al., 2007) occur more frequently among patients with type 2 diabetes. In contrast, a recent metaanalysis (Giovannucci et al., 2010) involving a total of nineteen studies, indicates a reduced risk of occurrence of $16 \%$ for prostate carcinoma in diabetic patients.

Several mechanisms could be involved in the initiation and/or progression of cancer in diabetes but these mechanisms still remain hypothetical.

Insulin and its associated receptor seem to have a key role, as well as the insulin-like growth factor 1 and its receptor, in the interplay between cancer and diabetes (Cohen and LeRoith, 2012). Furthermore, hyperglycemia could promote tumor progression due to increased intracellular metabolic activity specific to cancer cells and a greater membrane transport of glucose. Interestingly, it has been shown that the activation of pro-tumoral factors such as neutrophil elastase (NE; Moroy et al., 2012) and the accumulation of EDP in blood may represent inducible factors of insulin resistance in mice (Blaise et al., 2013). Indeed, $\mathrm{NE}^{-/-}$mice have increased blood glucose, decreased insulin pathway activity, and increased gluconeogenesis (Talukdar et al., 2012). This insulin resistance might be due to a decrease in the expression of Hsp90 and an increase of the inhibitory protein $(\mathrm{IkB})$ of the transcription 
factor NFkB. The pro-inflammatory state present in diabetics could decrease the efficiency of intracellular antioxidants and also participate in carcinogenesis. Some cytokines, such as tumor necrosis factor $\alpha$ (TNF- $\alpha)$, promote tumor growth by activating NF-кB (Szlosarek et al., 2006). Another mechanism related to the pro-inflammatory state, mitochondrial dysfunction, would be present in diabetic patients resulting in decreased energy available for DNA repair. Meanwhile, our laboratory has shown that EDP, which are products of NE activity, induce hyperglycemia and insulin resistance in animals by inhibiting insulin receptor signaling pathways in muscle, liver, and adipose tissue. Although the precise mechanism remains to be elucidated, it appears that this inhibitory effect involves a physical interaction between the insulin receptor and the ERC via its Neu-1 subunit (Blaise et al., 2013). Consequently, the ERC could not only exhibit a clear protumoral aspect, but is also involved in the outcome of diabetes influencing cancer development.

\section{Thrombosis}

Cancer-associated thrombosis is a major cause of morbidity and mortality in patients with cancer. Thrombotic complications, mostly from venous thromboembolism, are the second cause of death among patients with cancer (Khorana et al., 2007). Several mechanisms have been suggested to contribute to these increased thrombotic complications such as the prothrombotic activity of cancer cells (Mitrugno et al., 2015), the secondary deleterious effects of anti-cancer therapies and the interaction of cancer cells with blood platelets. Indeed, cumulative evidences show that platelets and their activation play important roles in cancer growth and dissemination (Gay and Felding-Habermann, 2011). Therefore, antiplatelet therapy to minimize platelet activation and aggregation, typically reserved for cardiovascular diseases, may have profound implications in cancer treatment (Franco et al., 2015).

In a recent study published by Kawecki et al. (2014), EDP were shown to decrease human platelet aggregation in whole blood and washed platelets. Both EDP and the VGVAPG peptide strongly reduced thrombus formation in vitro and in vivo in wild-type mice. Moreover, EDP and VGVAPG also prolonged tail bleeding times. The same study also reported that the regulatory role of EDP relies on a dual mechanism that involves effects on platelets, that express a functional ERC able to trigger an increase of platelet sialidase activity, and on the ability of EDP to

\section{REFERENCES}

Akhtar, R., Sherratt, M. J., Cruickshank, J. K., and Derby, B. (2011). Characterizing the elastic properties of tissues. Materialstoday 14, 96-105. doi: 10.1016/S13697021(11)70059-1

Amith, S. R., Jayanth, P., Finlay, T., Franchuk, S., Gilmour, A., Abdulkhalek, S., et al. (2010). Detection of Neul sialidase activity in regulating Toll-like receptor activation. J. Visual. Exp. 43. doi: 10.3791/2142

Antonicelli, F., Bellon, G., Debelle, L., and Hornebeck, W. (2007). Elastin-elastases and inflamm-aging. Curr. Top. Dev. Biol. 79, 99-155. doi: 10.1016/S00702153(06)79005-6

Archilla-Marcos, M., and Robert, L. (1993). Control of the biosynthesis and excretionof the elastase-type protease of human skin fibroblasts bythe elastin receptor. Clin. Physiol. Biochem. 10, 86-91. disrupt plasma von Willebrand factor interaction with collagen. Therefore, it is tempting to speculate that EDP may rather have beneficial effects on cancer-associated thrombosis by reducing platelet aggregation and thrombus formation.

However, if EDP modulate the formation of procoagulant microparticles by malignant cells and tissue factor expression of, the major molecular driver of cancer-associated coagulopathy and thromboembolic disorders (Mitrugno et al., 2015), remains unknown so far. Additional experiments are required to better understand the overall effects of elastin degradation products on cancer-associated thrombosis.

\section{CONCLUSION}

It is now admitted that ECM can directly influence cell fate and is involved in the phenotypic modulation of cells during cancer progression. Matrix-derived peptides, originating from tumor microenvironment degradation, are crucial actors involved in the pathology and a potential source of innovative therapy. Thus, among all the matrikines described up to now, bibliographic data show that elastokines and their singular receptor, present important pro-tumoral activities. Consequently, the targeting of the ERC is of particular interest as it is not only directly involved in cancer development where an important elastolysis is observed, but also in cancer-associated processes such as diabetes and thrombosis.

\section{AUTHOR CONTRIBUTIONS}

AS, LO, SS, AG, SB, CK, PM, HEB, BR-C, LM, LDe, LDu contributed to the writing of the paper and to its relecture. LO contributed to Table 1. AG contributed to Figure 1.

\section{FUNDING}

Works in the authors' laboratories were supported by funding from the Centre National de la Recherche Scientifique (CNRS) and Université de Reims Champagne Ardenne (URCA). AS was a fellowship recipient from Le Ministère de l'Enseignement Supérieur et de la Recherche. CK and AG are recipients of fellowships from the Région Champagne Ardenne.

Bax, D. V., Rodgers, U. R., Bilek, M. M., and Weiss, A. S. (2009). Cell adhesion to tropoelastin is mediated via the C-terminal GRKRK motif and integrin alphaVbeta3. J. Biol. Chem. 284, 28616-28623. doi: 10.1074/jbc.M109.017525

Bellon, G., Martiny, L., and Robinet, A. (2004). Matrix metalloproteinases and matrikines in angiogenesis. Crit. Rev. Oncol. 49, 203-220. doi: 10.1016/j.critrevonc.2003.10.004

Bisaccia, F., Morelli, M. A., De Biasi, M., Traniello, S., Spisani, S., and Tamburro, A. M. (1994). Migration of monocytes in the presence of elastolytic fragments of elastin and in synthetic derivates. Struct. Activ. Relationsh. Int. J. Peptide Prot. Res. 44, 332-341. doi: 10.1111/j.1399-3011.1994.tb01017.x

Blaise, S., Romier, B., Kawecki, C., Ghirardi, M., Rabenoelina, F., Baud, S., et al. (2013). Elastin-derived peptides are new regulators of insulin resistance development in mice. Diabetes 62, 3807-3816. doi: 10.2337/ db13-0508 
Blood, C. H., Sasse, J., Brodt, P., and Zetter, B. R. (1988). Identification of a tumor cell receptor for VGVAPG, an elastin-derived chemotactic peptide. J. Cell Biol. 107, 1987-1993. doi: 10.1083/jcb.107.5.1987

Blood, C. H., and Zetter, B. R. (1989). Membrane-bound protein kinase C modulates receptor affinity and chemotactic responsiveness of Lewis lung carcinoma sublines to an elastin-derived peptide. J. Biol. Chem. 264, 1061410620.

Blood, C. H., and Zetter, B. R. (1993). Laminin regulates a tumor cell chemotaxis receptor through the laminin-binding integrin subunit alpha 6. Cancer Res. 53, 2661-2666.

Brassart, B., Fuchs, P., Huet, E., Alix, A. J., Wallach, J., Tamburro, A. M., et al. (2001). Conformational dependence of collagenase (matrix metalloproteinase1) up-regulation by elastin peptides in cultured fibroblasts. J. Biol. Chem. 276, 5222-5227. doi: 10.1074/jbc.M003642200

Brassart, B., Randoux, A., Hornebeck, W., and Emonard, H. (1998). Regulation of matrix metalloproteinase-2 (gelatinase A, MMP-2), membranetype matrix metalloproteinase-1 (MT1-MMP) and tissue inhibitor of metalloproteinases-2 (TIMP-2) expression by elastin-derived peptides in human HT-1080 fibrosarcoma cell line. Clin. Exp. Metast. 16, 489-500. doi: 10.1023/A:1006550503612

Byzova, T. V., Rabbani, R., D'Souza, S. E., and Plow, E. F. (1998). Role of integrin alpha(v)beta3 in vascular biology. Thromb. Haemost. 80, 726-734.

Cantarelli, B., Duca, L., Blanchevoye, C., Poitevin, S., Martiny, L., and Debelle, L. (2009). Elastin peptides antagonize ceramide-induced apoptosis. FEBS Lett. 583, 2385-2391. doi: 10.1016/j.febslet.2009.06.037

Castiglione Morelli, M. A., Bisaccia, F., Spisani, S., De Biasi, M., Traniello, S., and Tamburro, A. M. (1997). Structure-activity relationships for some elastinderived peptide chemoattractants. J. Pept. Res. 49, 492-499. doi: 10.1111/j.13993011.1997.tb01156.x

Cohen, D. H., and LeRoith, D. (2012). Obesity, type 2 diabetes, and cancer: the insulin and IGF connection. Endocr. Relat. Cancer 19, F27-F45. doi: 10.1530/ERC-11-0374

Coquerel, B., Poyer, F., Torossian, F., Dulong, V., Bellon, G., Dubus, I., et al. (2009). Elastin-derived peptides: matrikines critical for glioblastoma cell aggressiveness in a 3-D system. Glia 57, 1716-1726. doi: 10.1002/glia. 20884

Daamen, W. F., Nillesen, S. T., Wismans, R. G., Reinhardt, D. P., Hafmans, T., Veerkamp, J. H., et al. (2008). A biomaterial composed of collagen and solubilized elastin enhances angiogenesis and elastic fiber formation without calcification. Tissue Eng. Part A 14, 349-360. doi: 10.1089/tea.2007.0076

Davis, G. E., Bayless, K. J., Davis, M. J., and Meininger, G. A. (2000). Regulation of tissue injury responses by the exposure of matricryptic sites within extracellular matrix molecules. Am. J. Pathol. 156, 1489-1498. doi: 10.1016/S0002-9440(10)65020-1

Devy, J., Duca, L., Cantarelli, B., Joseph-Pietras, D., Scandolera, A., Rusciani, A., et al. (2010). Elastin-derived peptides enhance melanoma growth in vivo by upregulating the activation of Mcol-A (MMP-1) collagenase. Br. J. Cancer 103, 1562-1570. doi: 10.1038/sj.bjc.6605926

Donet, M., Brassart-Pasco, S., Salesse, S., Maquart, F. X., and Brassart, B. (2014). Elastin peptides regulate HT-1080 fibrosarcoma cell migration and invasion through an Hsp90-dependent mechanism. Br. J. Cancer 111, 139-148. doi: $10.1038 /$ bjc. 2014.239

Duca, L., Blanchevoye, C., Cantarelli, B., Ghoneim, C., Dedieu, S., Delacoux, F., et al. (2007). The elastin receptor complex transduces signals through the catalytic activity of its Neu-1 subunit. J. Biol. Chem. 282, 12484-12491. doi: 10.1074/jbc.M609505200

Duca, L., Debelle, L., Debret, R., Antonicelli, F., Hornebeck, W., and Haye, B. (2002). The elastin peptides-mediated induction of pro-collagenase1 production by human fibroblasts involves activation of MEK/ERK pathway via PKA- and PI(3)K-dependent signaling. FEBS Lett. 524, 193-198. doi: 10.1016/S0014-5793(02)03057-0

Duca, L., Lambert, E., Debret, R., Rothhut, B., Blanchevoye, C., Delacoux, F., et al. (2005). Elastin peptides activate extracellular signal-regulated kinase $1 / 2$ via a Ras-independent mechanism requiring both p110gamma/Raf-1 and protein kinase A/B-Raf signaling in human skin fibroblasts. Mol. Pharmacol. 67, 1315-1324. doi: 10.1124/mol.104.002725

Dutoya, S., Verna, A., Lefèbvre, F., and Rabaud, M. (2000). Elastin-derived protein coating onto poly(ethylene terephthalate). Technical, microstructural and biological studies. Biomaterials 21, 1521-1529. doi: 10.1016/S01429612(99)00274-4

Fahem, A., Robinet, A., Cauchard, J. H., Duca, L., Soula-Rothhut, M., Rothhut, B., et al. (2008). Elastokine-mediated up-regulation of MT1-MMP is triggered by nitric oxide in endothelial cells. Int. J. Biochem. Cell Biol. 40, 1581-1596. doi: 10.1016/j.biocel.2007.11.022

Faury, G., Usson, Y., Robert-Nicoud, M., Robert, L., and Verdetti, J. (1998). Nuclear and cytoplasmic free calcium level changes induced by elastin peptides in human endothelial cells. Proc. Natl. Acad. Sci. U.S.A. 95, 2967-2972. doi: 10.1073/pnas.95.6.2967

Fortuna-Costa, A., Gomes, A. M., Kozlowski, E. O., Stelling, M. P., and Pavao, M. S. (2014). Extracellular galectin-3 in tumor progression and metastasis. Front. Oncol. 4:138. doi: 10.3389/fonc.2014.00138

Franco, A. T., Corken, A., and Ware, J. (2015). Platelets at the interface of thrombosis, inflammation, and cancer. Blood 126, 582-588. doi: 10.1182/blood2014-08-531582

Friberg, E., Orsini, N., Mantzoros, C. S., and Wolk, A. (2007). Diabetes mellitus and risk of endometrial cancer: a meta-analysis. Diabetologia 50, 1365-1374. doi: 10.1007/s00125-007-0681-5

Fujimoto, N., Tajima, S., and Ishibashi, A. (2000). Elastin peptides induce migration and terminal differentiation of cultured keratinocytes via 67 $\mathrm{kDa}$ elastin receptor in vitro: $67 \mathrm{kDa}$ elastin receptor is expressed in the keratinocytes eliminating elastic materials in elastosis perforans serpiginosa. J. Investig. Dermatol. 115, 633-639. doi: 10.1046/j.1523-1747.2000. 00117.x

Fülöp, T. Jr., Jacob, M. P., Varga, Z., Foris, G., Leovey, A., and Robert, L. (1986). Effect of elastin peptides on human monocytes: $\mathrm{Ca}^{2+}$ mobilization, stimulation of respiratory burst and enzyme secretion. Biochem. Biophys. Res. Commun. 141, 92-98. doi: 10.1016/S0006-291X(86)80339-4

Fulop, T. Jr., Wei, S. M., Robert, L., and Jacob, M. P. (1990). Determination of elastin peptides in normal and arteriosclerotic human sera by ELISA. Clin. Physiol. Biochem. 8, 273-282.

Gay, L. J., and Felding-Habermann, B. (2011). Contribution of platelets to tumour metastasis. Nat. Rev. Cancer 11, 123-134. doi: 10.1038/nrc3004

Ghuysen-Itard, A. F., Robert, L., and Jacob, M. P. (1992). [Effect of elastin peptides on cell proliferation]. Comp. Rendus Acad. Sci. Serie III Sci. 315, 473-478.

Giovannucci, E., Harlan, D. M., Archer, M. C., Bergenstal, R. M., Gapstur, S. M., Habel, L. A., et al. (2010). Diabetes and cancer: a consensus report. CA Cancer J. Clin. 60, 207-221. doi: 10.3322/caac.20078

Gminski, J., Weglarz, L., Drozdz, M., and Goss, M. (1991a). Pharmacological modulation of the antioxidant enzymes activities and the concentration of peroxidation products in fibroblasts stimulated with elastin peptides. Gen. Pharmacol. 22, 495-497. doi: 10.1016/0306-3623(91)90012-U

Gminski, J., Weglarz, L., Drozdz, M., Sulkowski, P., and Goss, M. (1991b). Modulation of elastase-like activity in fibroblasts stimulated with elastin peptides. Biochem. Med. Metab. Biol. 45, 254-257. doi: 10.1016/08854505(91)90028-J

Grosso, L. E., and Mecham, R. P. (1988). In vitro processing of tropoelastin: investigation of a possible transport function associated with the carboxyterminal domain. Biochem. Biophys. Res. Commun. 153, 545-551. doi: 10.1016/S0006-291X(88)81129-X

Grosso, L. E., and Scott, M. (1993a). Peptide sequences selected by BA4, a tropoelastin-specific monoclonal antibody, are ligands for the 67kilodalton bovine elastin receptor. Biochemistry 32, 13369-13374. doi: 10.1021/bi00211a052

Grosso, L. E., and Scott, M. (1993b). PGAIPG, a repeated hexapeptide of bovine tropoelastin, is a ligand for the $67-\mathrm{kDa}$ bovine elastin receptor. Matrix 13 , 157-164. doi: 10.1016/S0934-8832(11)80074-0

Groult, V., Hornebeck, W., Ferrari, P., Tixier, J. M., Robert, L., and Jacob, M. P. (1991). Mechanisms of interaction between human skin fibroblasts and elastin: differences between elastin fibres and derived peptides. Cell Biochem. Funct. 9, 171-182. doi: 10.1002/cbf.290090305

Gunda, V., Verma, R. K., and Sudhakar, Y. A. (2013). Inhibition of elastin peptidemediated angiogenic signaling mechanism(s) in choroidal endothelial cells by the alpha6(IV)NC1 collagen fragment. Investig. Ophthalmol. Vis. Sci. 54, 7828-7835. doi: 10.1167/iovs.12-10870

Guo, G., Booms, P., Halushka, M., Dietz, H. C., Ney, A., Stricker, S., et al. (2006). Induction of macrophage chemotaxis by aortic extracts of the mgR Marfan 
mouse model and a GxxPG-containing fibrillin-1 fragment. Circulation 114, 1855-1862. doi: 10.1161/CIRCULATIONAHA.105.601674

Guo, G., Gehle, P., Doelken, S., Martin-Ventura, J. L., von Kodolitsch, Y., Hetzer, R., et al. (2011). Induction of macrophage chemotaxis by aortic extracts from patients with Marfan syndrome is related to elastin binding protein. PLoS ONE 6:e20138. doi: 10.1371/journal.pone.0020138

Hance, K. A., Tataria, M., Ziporin, S. J., Lee, J. K., and Thompson, R. W. (2002). Monocyte chemotactic activity in human abdominal aortic aneurysms: role of elastin degradation peptides and the $67-\mathrm{kD}$ cell surface elastin receptor. J. Vasc. Surg. 35, 254-261. doi: 10.1067/mva.2002.120382

Hauck, M., Seres, I., Kiss, I., Saulnier, J., Mohacsi, A., Wallach, J., et al. (1995). Effects of synthesized elastin peptides on human leukocytes. Biochem. Mol. Biol. Int. 37, 45-55.

Heinz, A., Jung, M. C., Duca, L., Sippl, W., Taddese, S., Ihling, C., et al. (2010). Degradation of tropoelastin by matrix metalloproteinases-cleavage site specificities and release of matrikines. FEBS J. 277, 1939-1956. doi: $10.1111 / j .1742-4658.2010 .07616 . x$

Heinz, A., Jung, M. C., Jahreis, G., Rusciani, A., Duca, L., Debelle, L., et al. (2012). The action of neutrophil serine proteases on elastin and its precursor. Biochimie 94, 192-202. doi: 10.1016/j.biochi.2011.10.006

Hinek, A. (1994). Nature and the multiple functions of the $67-\mathrm{kD}$ elastin/laminin binding protein. Cell Adhesion Commun. 2, 185-193. doi: $10.3109 / 15419069409004436$

Hinek, A., Bodnaruk, T. D., Bunda, S., Wang, Y., and Liu, K. (2008). Neuraminidase-1, a subunit of the cell surface elastin receptor, desialylates and functionally inactivates adjacent receptors interacting with the mitogenic growth factors PDGF-BB and IGF-2. Am. J. Pathol. 173, 1042-1056. doi: 10.2353/ajpath.2008.071081

Hinek, A., Jung, S., and Rutka, J. T. (1999). Cell surface aggregation of elastin receptor molecules caused by suramin amplified signals leading to proliferation of human glioma cells. Acta Neuropathol. 97, 399-407. doi: $10.1007 / \mathrm{s} 004010051004$

Hinek, A., Keeley, F. W., and Callahan, J. (1995). Recycling of the 67-kDa elastin binding protein in arterial myocytes is imperative for secretion of tropoelastin. Exp. Cell Res. 220, 312-324. doi: 10.1006/excr.1995.1321

Hopps, E., and Caimi, G. (2012). Matrix metalloproteinases in metabolic syndrome. Eur. J. Int. Med. 23, 99-104. doi: 10.1016/j.ejim.2011. 09.012

Hornebeck, W., Tixier, J. M., and Robert, L. (1986). Inducible adhesion of mesenchymal cells to elastic fibers: elastonectin. Proc. Natl. Acad. Sci. U.S.A. 83, 5517-5520. doi: 10.1073/pnas.83.15.5517

Houghton, A. M., Quintero, P. A., Perkins, D. L., Kobayashi, D. K., Kelley, D. G., Marconcini, L. A., et al. (2006). Elastin fragments drive disease progression in a murine model of emphysema. J. Clin. Investig. 116, 753-759. doi: $10.1172 /$ JCI25617

Huet, E., Brassart, B., Cauchard, J. H., Debelle, L., Birembaut, P., Wallach, J., et al. (2002). Cumulative influence of elastin peptides and plasminogen on matrix metalloproteinase activation and type I collagen invasion by HT-1080 fibrosarcoma cells. Clin. Exp. Metastasis 19, 107-117. doi: 10.1023/A:1014547324918

Huet, E., Brassart, B., Wallach, J., Debelle, L., Haye, B., Emonard, H., et al. (2001). [Effect of elastin peptides on the production of matrix metalloproteinase 2 by human skin fibroblasts in culture]. J. Soc. Biol. 195, 165-172.

Hynes, R. O. (2009). The extracellular matrix: not just pretty fibrils. Science 326, 1216-1219. doi: 10.1126/science. 1176009

Ito, S., Ishimaru, S., and Wilson, S. E. (1998). Effect of coacervated alpha-elastin on proliferation of vascular smooth muscle and endothelial cells. Angiology 49, 289-297. doi: 10.1177/000331979804900407

Jacob, M. P., Fulop, T. Jr., Foris, G., and Robert, L. (1987). Effect of elastin peptides on ion fluxes in mononuclear cells, fibroblasts, and smooth muscle cells. Proc. Natl. Acad. Sci. U.S.A. 84, 995-999. doi: 10.1073/ pnas.84.4.995

Jayanth, P., Amith, S. R., Gee, K., and Szewczuk, M. R. (2010). Neul sialidase and matrix metalloproteinase- 9 cross-talk is essential for neurotrophin activation of Trk receptors and cellular signaling. Cell. Signal. 22, 1193-1205. doi: 10.1016/j.cellsig.2010.03.011

Jung, S., Hinek, A., Tsugu, A., Hubbard, S. L., Ackerley, C., Becker, L. E., et al. (1999). Astrocytoma cell interaction with elastin substrates: implications for astrocytoma invasive potential. Glia 25, 179-189. doi: 10.1002/(SICI)10981136(19990115)25:2<179::AID-GLIA8 > 3.0.CO;2-B

Jung, S., Rutka, J. T., and Hinek, A. (1998). Tropoelastin and elastin degradation products promote proliferation of human astrocytoma cell lines. J. Neuropathol. Exp. Neurol. 57, 439-448. doi: 10.1097/00005072-19980500000007

Kamisato, S., Uemura, Y., Takami, N., and Okamoto, K. (1997). Involvement of intracellular cyclic gmp and cyclic gmp-dependent protein kinase in $\alpha$-elastin-induced macrophage chemotaxis. J. Biochem. 121, 862-867. doi: 10.1093/oxfordjournals.jbchem.a021666

Kamoun, A., Landeau, J. M., Godeau, G., Wallach, J., Duchesnay, A., Pellat, B., et al. (1995). Growth stimulation of human skin fibroblasts by elastin-derived peptides. Cell Adhesion Commun. 3, 273-281. doi: 10.3109/15419069509081013

Kawecki, C., Hezard, N., Bocquet, O., Poitevin, G., Rabenoelina, F., Kauskot, A., et al. (2014). Elastin-derived peptides are new regulators of thrombosis. Arteriosc. Thromb. Vasc. Biol. 34, 2570-2578. doi: 10.1161/ATVBAHA.114.304432

Khorana, A. A., Francis, C. W., Culakova, E., Kuderer, N. M., and Lyman, G. H. (2007). Frequency, risk factors, and trends for venous thromboembolism among hospitalized cancer patients. Cancer 110, 2339-2346. doi: $10.1002 /$ cncr.23062

Kielty, C. M., Sherratt, M. J., and Shuttleworth, C. A. (2002). Elastic fibres. J. Cell Sci. $115,2817-2828$.

Landeau, J. M., Pellat, B., and Hornebeck, W. (1994). Increased secretion of latent elastase activity following contact between human skin fibroblasts and elastin derived peptides. Cell Biol. Int. 18, 111-117. doi: 10.1006/cbir.1994.1050

Larsson, S. C., Mantzoros, C. S., and Wolk, A. (2007). Diabetes mellitus and risk of breast cancer: a meta-analysis. Int. J. Cancer 121, 856-862. doi: $10.1002 / \mathrm{ijc} .22717$

Larsson, S. C., Orsini, N., Brismar, K., and Wolk, A. (2006). Diabetes mellitus and risk of bladder cancer: a meta-analysis. Diabetologia 49, 2819-2823. doi: 10.1007/s00125-006-0468-0

Larsson, S. C., Orsini, N., and Wolk, A. (2005). Diabetes mellitus and risk of colorectal cancer: a meta-analysis. J. Natl. Cancer Instit. 97, 1679-1687. doi: 10.1093/jnci/dji375

Lee, C., Liu, A., Miranda-Ribera, A., Hyun, S. W., Lillehoj, E. P., Cross, A. S., et al. (2014a). NEU1 sialidase regulates the sialylation state of CD31 and disrupts CD31-driven capillary-like tube formation in human lung microvascular endothelia. J. Biol. Chem. 289, 9121-9135. doi: 10.1074/jbc.M114.555888

Lee, P., Bax, D. V., Bilek, M. M., and Weiss, A. S. (2014b). A novel cell adhesion region in tropoelastin mediates attachment to integrin alphaVbeta5. J. Biol. Chem. 289, 1467-1477. doi: 10.1074/jbc.M113.518381

Lillehoj, E. P., Hyun, S. W., Feng, C., Zhang, L., Liu, A., Guang, W., et al. (2012). NEU1 sialidase expressed in human airway epithelia regulates epidermal growth factor receptor (EGFR) and MUC1 protein signaling. J. Biol. Chem. 287, 8214-8231. doi: 10.1074/jbc.M111.292888

Long, M. M., King, V. J., Prasad, K. U., Freeman, B. A., and Urry, D. W. (1989). Elastin repeat peptides as chemoattractants for bovine aortic endothelial cells. J. Cell. Physiol. 140, 512-518. doi: 10.1002/jcp.1041400316

Magesh, S., Savita, V., Moriya, S., Suzuki, T., Miyagi, T., Ishida, H., et al. (2009). Human sialidase inhibitors: design, synthesis, and biological evaluation of 4-acetamido-5-acylamido-2-fluoro benzoic acids. Bioorg. Med. Chem. 17, 45954603. doi: 10.1016/j.bmc.2009.04.065

Maquart, F. X., Bellon, G., Pasco, S., and Monboisse, J. C. (2005). Matrikines in the regulation of extracellular matrix degradation. Biochimie 87, 353-360. doi: 10.1016/j.biochi.2004.10.006

Maquart, F. X., Pasco, S., Ramont, L., Hornebeck, W., and Monboisse, J. C. (2004). An introduction to matrikines: extracellular matrix-derived peptides which regulate cell activity. Implication in tumor invasion. Crit. Rev. Oncol. 49, 199-202. doi: 10.1016/j.critrevonc.2003.06.007

Mecham, R. P., Hinek, A., Griffin, G. L., Senior, R. M., and Liotta, L. A. (1989). The elastin receptor shows structural and functional similarities to the $67-\mathrm{kDa}$ tumor cell laminin receptor. J. Biol. Chem. 264, 16652-16657.

Mecham, R. P., Whitehouse, L., Hay, M., Hinek, A., and Sheetz, M. P. (1991). Ligand affinity of the $67-\mathrm{kD}$ elastin/laminin binding protein is modulated by the protein's lectin domain: visualization of elastin/laminin-receptor complexes with gold-tagged ligands. J. Cell Biol. 113, 187-194. doi: 10.1083/jcb.113. 1.187 
Mithieux, S. M., and Weiss, A. S. (1995). Tandem integration of multiple ILV5 copies and elevated transcription in polyploid yeast. Yeast 11, 311-316. doi: 10.1002/yea.320110403

Mitrugno, A., Tormoen, G. W., Kuhn, P., and McCarty, O. J. (2015). The prothrombotic activity of cancer cells in the circulation. Blood Rev. doi: 10.1016/j.blre.2015.07.001 [Epub ahead of print].

Moroy, G., Alix, A. J., Sapi, J., Hornebeck, W., and Bourguet, E. (2012). Neutrophil elastase as a target in lung cancer. Anti Cancer Agents Med. Chem. 12, 565-579. doi: $10.2174 / 187152012800617696$

Morrison, M. (2012). Pancreatic cancer and diabetes. Adv. Exp. Med. Biol. 771, 229-239.

Nackman, G. B., Karkowski, F. J., Halpern, V. J., Gaetz, H. P., and Tilson, M. D. (1997). Elastin degradation products induce adventitial angiogenesis in the Anidjar/Dobrin rat aneurysm model. Surgery 122, 39-44. doi: 10.1016/S00396060(97)90262-2

Nowak, D., Glowczynska, I., and Piasecka, G. (1989). Chemotactic activity of elastin-derived peptides for human polymorphonuclear leukocytes and their effect on hydrogen peroxide and myeloperoxidase release. Arch. Immunol. Ther. Exp. 37, 741-748.

Ntayi, C., Labrousse, A. L., Debret, R., Birembaut, P., Bellon, G., Antonicelli, F., et al. (2004). Elastin-derived peptides upregulate matrix metalloproteinase-2mediated melanoma cell invasion through elastin-binding protein. J. Investig. Dermatol. 122, 256-265. doi: 10.1046/j.0022-202X.2004.22228.x

Ochieng, J., Furtak, V., and Lukyanov, P. (2004). Extracellular functions of galectin3. Glycoc. J. 19, 527-535. doi: 10.1023/B:GLYC.0000014082.99675.2f

O'Shea, L. K., Abdulkhalek, S., Allison, S., Neufeld, R. J., and Szewczuk, M. R. (2014). Therapeutic targeting of Neul sialidase with oseltamivir phosphate $(\operatorname{Tamiflu}(\mathrm{R}))$ disables cancer cell survival in human pancreatic cancer with acquired chemoresistance. OncoTarg. Ther. 7, 117-134. doi: 10.2147/OTT.S55344

Parsons, B. L. (2008). Many different tumor types have polyclonal tumor origin: evidence and implications. Mutat. Res. 659, 232-247. doi: 10.1016/j.mrrev.2008.05.004

Petersen, E., Wagberg, F., and Angquist, K. A. (2002). Serum concentrations of elastin-derived peptides in patients with specific manifestations of atherosclerotic disease. Eur. J. Vasc. Endovasc. Surg. 24, 440-444. doi: 10.1053/ejvs.2002.1750

Péterszegi, G., and Robert, L. (1998). Cell death induced in lymphocytes expressing the elastin-laminin receptor by excess agonists: necrosis and apoptosis. Biomed. Pharmacother. 52, 369-377. doi: 10.1016/S0753-3322(99)80004-3

Péterszegi, G., Robert, A. M., and Robert, L. (1996). Presence of the elastinlaminin receptor on human activated lymphocytes. Compt. Rendus Acad. Sci. 319, 799-803.

Péterszegi, G., Texier, S., and Robert, L. (1997). Human helper and memory lymphocytes exhibit an inducible elastin-laminin receptor. Int. Arch. Allergy Immunol. 114, 218-223. doi: 10.1159/000237671

Péterszegi, G., Texier, S., and Robert, L. (1999). Cell death by overload of the elastin-laminin receptor on human activated lymphocytes: protection by lactose and melibiose. Eur. J. Clin. Investig. 29, 166-172. doi: 10.1046/j.13652362.1999.00423.x

Pocza, P., Suli-Vargha, H., Darvas, Z., and Falus, A. (2008). Locally generated VGVAPG and VAPG elastin-derived peptides amplify melanoma invasion via the galectin-3 receptor. Int. J. Cancer J. Int. Cancer 122, 1972-1980. doi: $10.1002 /$ ijc. 23296

Poggi, A., and Mingari, M. C. (1995). Development of human NK cells from the immature cell precursors. Semin. Immunol. 7, 61-66. doi: 10.1006/smim.1995.0009

Privitera, S., Prody, C. A., Callahan, J. W., and Hinek, A. (1998). The 67-kDa enzymatically inactive alternatively spliced variant of beta-galactosidase is identical to the elastin/laminin-binding protein. J. Biol. Chem. 273, 6319-6326. doi: 10.1074/jbc.273.11.6319

Pshezhetsky, A. V., and Hinek, A. (2011). Where catabolism meets signalling: neuraminidase 1 as a modulator of cell receptors. Glycoc. J. 28, 441-452. doi: 10.1007/s10719-011-9350-5

Robinet, A., Fahem, A., Cauchard, J. H., Huet, E., Vincent, L., Lorimier, S., et al. (2005). Elastin-derived peptides enhance angiogenesis by promoting endothelial cell migration and tubulogenesis through upregulation of MT1MMP. J. Cell Sci. 118, 343-356. doi: 10.1242/jcs.01613
Robinet, A., Millart, H., Oszust, F., Hornebeck, W., and Bellon, G. (2007). Binding of elastin peptides to S-Gal protects the heart against ischemia/reperfusion injury by triggering the RISK pathway. FASEB J. 21, 1968-1978. doi: 10.1096/fj.06-6477com

Rodgers, U. R., and Weiss, A. S. (2004). Integrin alpha v beta 3 binds a unique nonRGD site near the C-terminus of human tropoelastin. Biochimie 86, 173-178. doi: 10.1016/j.biochi.2004.03.002

Rodgers, U. R., and Weiss, A. S. (2005). Cellular interactions with elastin. Pathol. Biol. 53, 390-398. doi: 10.1016/j.patbio.2004.12.022

Rusciani, A., Duca, L., Sartelet, H., Chatron-Colliet, A., Bobichon, H., Ploton, D., et al. (2010). Elastin peptides signaling relies on neuraminidase1-dependent lactosylceramide generation. PLoS ONE 5:e14010. doi: 10.1371/journal.pone.0014010

Scandolera, A., Rabenoelina, F., Chaintreuil, C., Rusciani, A., Maurice, P., Blaise, S., et al. (2015). Uncoupling of elastin complex receptor during in vitro aging is related to modifications in its intrinsic sialidase activity and the subsequent lactosylceramide production. PLoS ONE 10:e0129994. doi: 10.1371/journal.pone.0129994

Senior, R. M., Griffin, G. L., and Mecham, R. P. (1980). Chemotactic activity of elastin-derived peptides. J. Clin. Investig. 66, 859-862. doi: 10.1172/JCI109926

Senior, R. M., Griffin, G. L., and Mecham, R. P. (1982). Chemotactic responses of fibroblasts to tropoelastin and elastin-derived peptides. J. Clin. Investig. 70, 614-618. doi: 10.1172/JCI110654

Senior, R. M., Griffin, G. L., Mecham, R. P., Wrenn, D. S., Prasad, K. U., and Urry, D. W. (1984). Val-Gly-Val-Ala-Pro-Gly, a repeating peptide in elastin, is chemotactic for fibroblasts and monocytes. J. Cell Biol. 99, 870-874. doi: $10.1083 /$ jcb.99.3.870

Shiratsuchi, E., Ura, M., Nakaba, M., Maeda, I., and Okamoto, K. (2010). Elastin peptides prepared from piscine and mammalian elastic tissues inhibit collagen-induced platelet aggregation and stimulate migration and proliferation of human skin fibroblasts. J. Peptide Sci. 16, 652-658. doi: 10.1002/ psc. 1277

Siemianowicz, K., Gminski, J., Goss, M., Francuz, T., Likus, W., Jurczak, T., et al. (2010). Influence of elastin-derived peptides on metalloprotease production in endothelial cells. Exp. Ther. Med. 1, 1057-1060.

Siemianowicz, K., Likus, W., Francuz, T., and Garczorz, W. (2015). Effect of elastinderived peptides on the production of tissue inhibitor of metalloproteinase-1, -2 , and -3 and the ratios in various endothelial cell lines. Exp. Ther. Med. 9, 2245-2250.

Skeie, J. M., Hernandez, J., Hinek, A., and Mullins, R. F. (2012). Molecular responses of choroidal endothelial cells to elastin derived peptides through the elastin-binding protein (GLB1). Matrix Biol. 31, 113-119. doi: 10.1016/j.matbio.2011.11.003

Skeie, J. M., and Mullins, R. F. (2008). Elastin-mediated choroidal endothelial cell migration: possible role in age-related macular degeneration. Investig. Ophthalmol. Vis. Sci. 49, 5574-5580. doi: 10.1167/ iovs.08-1984

Svitkina, T. M., and Parsons, D. F. (1993). Binding of some metastatic tumor cell lines to fibrous elastin and elastin peptides. Int. J. Cancer 53, 824-828. doi: 10.1002/ijc. 2910530520

Swee, M. H., Parks, W. C., and Pierce, R. A. (1995). Developmental regulation of elastin production. Expression of tropoelastin pre-mRNA persists after downregulation of steady-state mRNA levels. J. Biol. Chem. 270, 14899-14906. doi: $10.1074 /$ jbc. 270.25 .14899

Szlosarek, P., Charles, K. A., and Balkwill, F. R. (2006). Tumour necrosis factor-alpha as a tumour promoter. Eur. J. Cancer 42, 745-750. doi: 10.1016/j.ejca.2006.01.012

Tajima, S., Wachi, H., Uemura, Y., and Okamoto, K. (1997). Modulation by elastin peptide VGVAPG of cell proliferation and elastin expression in human skin fibroblasts. Arch. Dermatol. Res. 289, 489-492. doi: 10.1007/s004030 050227

Talukdar, S., Oh da, Y., Bandyopadhyay, G., Li, D., Xu, J., McNelis, J., et al. (2012). Neutrophils mediate insulin resistance in mice fed a high-fat diet through secreted elastase. Nat. Med. 18, 1407-1412. doi: 10.1038/nm.2885

Timar, J., Lapis, K., Fulop, T., Varga, Z. S., Tixier, J. M., Robert, L., et al. (1991). Interaction between elastin and tumor cell lines with different metastatic potential; in vitro and in vivo studies. J. Cancer Res. Clin. Oncol. 117, 232-238. doi: $10.1007 / \mathrm{BF} 01625430$ 
Toupance, S., Brassart, B., Rabenoelina, F., Ghoneim, C., Vallar, L., Polette, M., et al. (2012). Elastin-derived peptides increase invasive capacities of lung cancer cells by post-transcriptional regulation of MMP-2 and uPA. Clin. Exp. Metast. 29, 511-522. doi: 10.1007/s10585-012-9467-3

Tyagi, S. C., Kumar, S. G., Alla, S. R., Reddy, H. K., Voelker, D. J., and Janicki, J. S. (1996). Extracellular matrix regulation of metalloproteinase and antiproteinase in human heart fibroblast cells. J. Cell. Physiol. 167, 137-147. doi: 10.1002/(SICI)1097-4652(199604)167:1 < 137::AID-JCP16>3.0.CO;2-8

Uemura, Y., and Okamoto, K. (1997). Elastin-derived peptide induces monocyte chemotaxis by increasing intracellular cyclic GMP level and activating cyclic GMP dependent protein kinase. Biochem. Mol. Biol. Int. 41, 1085-1092. doi: $10.1080 / 15216549700201061$

Uitto, J., Christiano, A. M., Kahari, V. M., Bashir, M. M., and Rosenbloom, J. (1991). Molecular biology and pathology of human elastin. Biochem. Soc. Trans. 19, 824-829. doi: 10.1042/bst0190824

Varga, Z., Jacob, M. P., Robert, L., Csongor, J., and Fulop, T. Jr. (1997). Age-dependent changes of K-elastin stimulated effector functions of human phagocytic cells: relevance for atherogenesis. Exp. Gerontol. 32, 653-662. doi: 10.1016/S0531-5565(97)00042-9
Yamamoto, M., Akazawa, K., Aoyagi, M., Yamamoto, N., and Yamamoto, K. (2002). Changes in elastin-binding protein in fibroblasts derived from cardinal ligaments of patients with prolapsus uteri. Cell Biol. Int. 26, 441-449. doi: 10.1006/cbir.2002.0877

Yusa, T., Blood, C. H., and Zetter, B. R. (1989). Tumor cell interactions with elastin: implications for pulmonary metastasis. Am. Rev. Respir. Dis. 140, 1458-1462. doi: $10.1164 /$ ajrccm/140.5.1458

Conflict of Interest Statement: The authors declare that the research was conducted in the absence of any commercial or financial relationships that could be construed as a potential conflict of interest.

Copyright (c) 2016 Scandolera, Odoul, Salesse, Guillot, Blaise, Kawecki, Maurice, El Btaouri, Romier-Crouzet, Martiny, Debelle and Duca. This is an open-access article distributed under the terms of the Creative Commons Attribution License (CC BY). The use, distribution or reproduction in other forums is permitted, provided the original author(s) or licensor are credited and that the original publication in this journal is cited, in accordance with accepted academic practice. No use, distribution or reproduction is permitted which does not comply with these terms. 